\title{
ANALISIS BUTIR SOAL UJIAN SEMESTER MATA PELAJARAN KIMIA KELAS X MADRASAH ALIYAH DI KECAMATAN PASIR PENYU
}

\author{
Putri Sakinah $^{1)}$, Pangoloan Soleman Ritonga \\ ${ }^{1}$ Fakultas Tarbiyah dan Keguruan, UIN SUSKA RIAU \\ Email:pu3sakinah@gmail.com
}

\begin{abstract}
This research is motivated by the exam questions in the odd semester of 2015/2016 of which items have not been analyzed. Furthermore, the test result of the odd semester is under the minimum completion criteria. This document analysis research is aimed at discovering the quality of question items qualitatively and quantitatively. The result of the study suggests that 40 items of the odd semester chemistry subject exam questions are not qualitatively compliance with all material aspects, constructions, and the language examined from class 10 of Islamic Senior High School Ponpes Khairul Ummah. Furthermore, at MA Nurul Falah, there are 19 items which are not compliance with the aspect of materials, constructions, and the language that is examined. Quantitatively, there are 29 valid items at MA Ponpes Khairul Ummah and possess test reliability as many as 0.65. At MA Nurul Falah there are 31 valid items and possess test reliability as much as 0.76 .
\end{abstract}

Keywords: Analysis of grain problem, chemistry, qualitative, quantitative

\section{PENDAhUluan}

Interaksi belajar mengajar diprioritaskan pada profesionalisme guru dan prestasi belajar siswa dengan menitikberatkan pada kebermutuan sumber ajar. Keterkaitan antarkomponen pembelajaran dijalankan selaras dengan konteks pembelajaran dan berpedoman pada tujuan yang akan dicapai. Tujuan pembelajaran yang telah dirancang, sesuai dengan silabus, menjadi tolok ukur keberhasilan belajar siswa.[1] Pencapaian tujuan pembelajaran dapat diukur dengan suatu kegiatan yang disebut dengan evaluasi.

Evaluasi pendidikan adalah kegiatan atau proses penentuan nilai pendidikan sehingga dapat diketahui mutu atau hasil-hasilnya. Evaluasi pada proses pelaksanaan pengajaran akan mencakup kesesuaian antara proses belajar mengajar yang berlangsung, dengan garis-garis besar program pengajaran yang telah ditentukan, dan kesiapan guru dalam melaksanakan program pengajaran, dan sebagainya.[2] Alat evaluasi yang digunakan guru di sekolah untuk mengukur penguasaan ilmu yang dipelajari oleh siswa adalah tes.
Berdasarkan jenis tes sebagai pengukur keberhasilan atau kemampuan siswa, Ulangan Tengah Semester (UTS) maupun Ulangan Akhir Semester (UAS) pada jenjang pendidikan SMA sederajat tergolong pada tes sumatif. Tes sumatif dilakukan setelah selesai semua kegiatan belajar mengajar atau seluruh program yang direncanakan. Materi yang diujikan pada tes sumatif mencakup semua kompetensi dasar yang telah diajarkan dalam setengah/satu semester. Dengan demikian, tes sumatif dilaksanakan untuk mencapai tujuan umum pembelajaran sesuai dengan standar kompetensi yang telah ditetapkan.[1] Untuk mengetahui kualitas tes yang diberikan kepada siswa, guru perlu melakukan uji kriteria instrumen penilaian hasil belajar melalui analisis butir soal.

Pada akhir pembelajaran di sekolah, tes telah diberikan kepada siswa. Namun kendala yang dihadapi oleh guru adalah tes yang diberikan belum dianalisis butir soal. Sehingga kualitas butir soal yang diberikan belum diketahui.

Kualitas butir soal ini memiliki hubungan dengan hasil belajar siswa. Apabila proses 
pembelajaran yang dilakukan selama satu semester sudah berlangsung baik, antara guru dan siswa juga sudah bekerja sama untuk mendapatkan hasil yang maksimal. Namun hasil yang didapat ternyata tidak memuaskan. Salah satu faktor penyebabnya mungkin saja karena kualitas butir soal yang rendah atau buruk.

Hasil wawancara dengan guru mata pelajaran kimia MA di Kecamatan Pasir Penyu Kabupaten Indragiri Hulu, soal ujian semester ganjil tahun ajaran 2015/2016 untuk kelas X belum dilakukan analisis butir soal. Kemudian hasil ujian semester ganjil siswa rata-rata di bawah Kriteria Ketuntasan Minimal (KKM). Sehingga perlu di lakukan analisis butir soal terhadap soal ujian semester ganjil.

Analisis butir soal bertujuan untuk mengetahui kualitas butir soal ujian semester ganjil mata pelajaran kimia kelas $\mathrm{X}$ MA di Kecamatan Pasir Penyu Kabupaten Indragiri Hulu tahun pelajaran 2015/2016 ditinjau dari segi materi, konstruksi, dan bahasa (analisa kualitatif) dan ditinjau dari validitas item, reliabilitas, tingkat kesukaran, daya pembeda, dan fungsi distraktor instrumen tes hasil belajar (analisa kuantitatif).

Berdasarkan latar belakang tersebut, peneliti tertarik untuk melakukan penelitian dengan judul Analisis butir soal ujian semester ganjil mata pelajaran kimia kelas X Madrasah Aliyah di Kecamatan Pasir Penyu Kabupaten Indragiri Hulu.

\section{METODE PENELITIAN \\ Jenis Penelitian}

Penelitian ini merupakan penelitian analisis dokumen dengan menggunakan pendekatan deskriptif kualitatif dan kuantitatif. Pada penelitian ini peneliti berusaha menggambarkan dan menginterpertasikan kualitas butir soal ujian semester. Penelitian dilakukan secara kualitatif dan kuantitatif (mixed methods).

\section{Waktu dan Tempat Penelitian}

Penelitian ini dilaksanakan pada semester genap tahun ajaran 2015/2016. Penelitian ini dilaksanakan pada MA di Kecamatan Pasir Penyu Kabupaten Indragiri Hulu yaitu MA Pondok Pesantren Khairul Ummah Batu Gajah dan MA Nurul Falah Air Molek Kabupaten Indragiri Hulu.

\section{Objek dan Subjek Penelitian}

Objek penelitian adalah silabus, RPP, kisikisi soal, lembar soal dan lembar jawaban siswa pada ujian semester ganjil mata pelajaran kimia kelas X MA di Kecamatan Pasir Penyu Kabupaten Indragiri Hulu tahun pelajaran 2015/2016. Subjek penelitian ini adalah seluruh siswa kelas X MA di Kecamatan Pasir Penyu Kabupaten Indragiri Hulu.

\section{Populasi dan Sampel Penelitian}

Populasi dalam penelitian ini adalah instrument penilaian hasil belajar kimia pada MA di Kecamatan Pasir Penyu Kabupaten Indragiri Hulu. Sedangkan sampel dalam penelitian ini adalah instrument penilaian hasil belajar kimia kelas X MA di Kecamatan Pasir Penyu Kabupaten Indragiri Hulu.

\section{Teknik Pengumpulan Data}

Teknik pengumpulan data pada penelitian ini menggunakan wawancara dan dokumentasi.

\section{Teknik Analisis Data}

Analisis soal ujian semester ganjil mata pelajaran kimia kelas X MA di Kecamatan Pasir Penyu Kabupaten Indragiri Hulu tahun ajaran 2015/2016 dilakukan secara kualitatif dan kuantitatif. Analisis kualitatif mencakup pertimbangan soal dari segi materi, konstruksi, dan bahasa. Analisis kuantitatif butir soal dilakukan secara statistik yaitu analisis validitas butir soal, reliabilitas soal, tingkat kesukaran, daya pembeda, dan fungsi distraktor.

a. Analisis Kualitatif

Pada analisis butir soal secara kualitatif digunakan format penelaahan soal bentuk pilihan ganda sebagai berikut:[3]

Tabel 1. Format Penelaahan Butir Soal Bentuk Pilihan Ganda

Mata Pelajaran

Kelas/ Semester :

Penelaah

No.

Aspek yang ditelaah

$\begin{array}{ll}\text { A } & \text { Materi } \\ 1 & \begin{array}{l}\text { Soal sesuai dengan indikator } \\ \text { (menuntut tes tertulis untuk pilihan } \\ \text { ganda). }\end{array}\end{array}$




\section{No. Aspek yang ditelaah}

2 Materi yang dinyatakan sesuai dengan kompetensi (urgensi, relevansi, kontinuitas, keterpakaian sehari-hari tinggi).

3 Pilihan jawaban homogen dan logis.

4 Hanya ada satu kunci jawaban.

$\begin{array}{lll}\text { B } & \text { Konstruksi } \\ 1 & \text { Pokok soal dirumuskan dengan }\end{array}$ singkat, jelas, dan tegas.

2 Rumusan pokok soal dan pilihan jawaban merupakan pernyataan yang diperlukan saja.

3 Pokok soal tidak memberi petunjuk kunci jawaban.

4 Pokok soal bebas dari pernyataan yang bersifat negatif ganda.

5 Pilihan jawaban homogen dan logis ditinjau dari segi materi.

6 Gambar, grafik, tabel, diagram, atau sejenisnya jelas dan berfungsi.

7 Panjang pilihan jawaban relatif sama.

8 Pilihan jawaban tidak menggunakan pernyataan "semua jawaban di atas salah/benar" dan sejenisnya.

9 Pilihan jawaban berbentuk angka/waktu disusun berdasarkan urutan besar kecilnya angka atau kronologisnya.

10 Butir soal tidak bergantung pada jawaban soal sebelumnya.

Bahasa/Budaya

C Menggunakan bahasa yang sesuai

1 dengan kaidah bahasa Indonesia. Menggunakan bahasa yang

2 komunikatif.

Tidak menggunakan bahasa yang

3 berlaku setempat/ tabu. Pilihan jawaban tidak mengulang

$4 \quad$ kata/kelompok kata yang sama, kecuali merupakan suatu kesatuan pengertian. Kalimat soal tidak menyalin/menjiplak

5 persis teks bacaan.

Kalimat dalam pokok soal tidak

6 menyinggung pribadi seseorang, suku, ras, dan agama.

b. Analisis Kuantitatif
1) Validitas Butir Soal

Uji validitas butir soal dihitung menggunakan teknik korelasi point biserial dengan rumus:[4]

$$
\gamma_{p b i}=\frac{M_{p}-M_{t}}{S_{t}} \sqrt{\frac{p}{q}}
$$

Keterangan:

$\gamma_{p b i}=$ koefisien korelasi biserial

$M_{p}=$ rerata skor dari subjek yang

menjawab betul bagi item yang dicari

validitasnya.

$M_{t}=$ rerata skor total

$S_{t}=$ standar deviasi dari skor total proporsi

$p$ = proporsi siswa yang menjawab benar $p=\frac{\text { banyaknya siswa yang benar }}{\text { jumlah seluruh siswa }}$

$q$ = proporsi siswa yang menjawab salah $(q=1-p)$

2) Reliabilitas

Reliabilitas tes hasil belajar dihitung menggunakan pendekatan single test-single trial dengan menggunakan formula KuderRichardson $\left(\mathrm{KR}_{20}\right)$ dengan rumus:[4]

$$
r_{11}=\left(\frac{n}{n-1}\right)\left(\frac{S^{2}-\sum p q}{S^{2}}\right)
$$

Keterangan:

$r_{11}=$ reliabilitas tes secara keseluruhan

$p=$ proporsi subjek yang menjawab item dengan benar

$q \quad=$ proporsi subjek yan menjawab item dengan salah

$(q=1-p)$

$\sum p q=$ jumlah hasil perkalian antara $\mathrm{p}$ dan $\mathrm{q}$

$n \quad$ = banyaknya item

$S=$ standar deviasi dari tes (standar deviasi adalah akar varians)

3) Tingkat Kesukaran

Tingkat kesulitas item tes dihitung menggunakan rumus yang dikemukakan oleh $D u$ Bois, yaitu:

$$
P=\frac{B}{J S}
$$

Keterangan:

$P=$ proporsi $=$ angka indek kesukaran item 
$B$ = banyaknya testee yang menjawab dengan betul

$J S=$ jumlah testee yang mengikuti tes hasil belajar

4) Daya Pembeda

Rumus untuk menentukan indeks diskriminasi adalah:[4]

$$
D=\frac{B_{A}}{J_{A}}-\frac{B_{B}}{J_{B}}=P_{A}-P_{B}
$$

Keterangan:

$D$ = angka indeks diskriminasi

$J_{A}=$ banyaknya peserta tes kelompok atas

$J_{B}=$ banyaknya peserta tes kelompok bawah

$B_{A}=$ banyaknya peserta kelompok atas yang menjawab soal itu dengan benar

$B_{B}$ = banyaknya peserta kelompok bawah yang menjawab soal itu dengan benar

$P_{A}=$ proporsi peserta kelompok atas yang menjawab benar

$P_{B}=$ proporsi peserta kelompok bawah yang menjawab benar

5) Fungsi Distraktor (pengecoh) Indeks pengecoh dihitung dengan rumus:[5]

$$
I P=\frac{P}{(N-B) /(n-1)} \times 100 \%
$$

Keterangan:

IP = indeks pengecoh

$\mathrm{P}=$ jumlah siswa yang memilih pengecoh

$\mathrm{N}=$ jumlah siswa yang mengikuti tes

$\mathrm{B}=$ jumlah siswa yang menjawab benar pada setiap soal

$\mathrm{N}=$ jumlah alternative jawaban (opsi)

1 = bilangan tetap

\section{HASIL DAN PEMBAHASAN}

Tabel 2. Hasil Analisis Butir Soal dari Segi Materi, Konstruksi, dan Bahasa MA Ponpes Khairul Ummah Batu Gajah

\begin{tabular}{ccc}
\hline $\begin{array}{c}\text { Aspek } \\
\text { yang di } \\
\text { telaah }\end{array}$ & \multicolumn{2}{c}{$\begin{array}{c}\text { Soal yang tidak sesuai } \\
\text { dengan aspek yang ditelaah }\end{array}$} \\
\cline { 2 - 3 } & Jumlah soal & Persentase \\
\hline Materi & 13 & $32,5 \%$ \\
\hline Konstruksi & 8 & $20 \%$ \\
\hline $\begin{array}{c}\text { Bahasa/ } \\
\text { Budaya }\end{array}$ & 5 & $12,5 \%$ \\
\hline
\end{tabular}

Tabel 3. Hasil Analisis Butir Soal Dari Segi Materi, Konstruksi, dan Bahasa MA Nurul Falah Air Molek

\begin{tabular}{ccc}
\hline \multirow{2}{*}{$\begin{array}{c}\text { Aspek } \\
\text { yang di } \\
\text { telaah }\end{array}$} & \multicolumn{2}{c}{$\begin{array}{c}\text { Soal yang tidak sesuai dengan } \\
\text { aspek yang ditelaah }\end{array}$} \\
\cline { 2 - 3 } & Jumlah soal & Persentase \\
\hline Materi & 9 & $22,5 \%$ \\
\hline Konstruksi & 12 & $30 \%$ \\
\hline $\begin{array}{c}\text { Bahasa/ } \\
\text { Budaya }\end{array}$ & 11 & $27,5 \%$ \\
\hline
\end{tabular}

Pada analisis kualitatif terdapat 15 soal memiliki indikator soal yang tidak sesuai dengan indikator RPP. Pada kisi-kisi soal yang selanjutnya digunakan untuk membuat soal, indikator soal tidak spesifik menunjukkan kepada soal, sehingga soal yang dibuat belum dapat mengukur sejauh mana pencapaian siswa terhadap indikator pembelajaran.

Hal yang perlu diperhatikan dalam membuat soal adalah dalam memilih pilihan jawaban. Pada analisis kualitatif terdapat 9 soal memiliki pilihan jawaban tidak homogen dan logis. Pada pembuatan pilihan jawaban, semua pilihan jawaban harus berasal dari materi yang sama seperti dinyatakan pada pokok soal, penulisan semua pilihan jawaban harus setara, memiliki panjang relatif sama, dan tidak menggunakan pernyataan "semua jawaban diatas benar/salah"; sehingga pilihan jawaban dapat berfungsi dengan baik.

Pokok soal harus dirumuskan dengan singkat, jelas, tegas, dan merupakan pernyataan yang diperlukan saja. Jika terdapat pernyataan yang sebenarnya tidak diperlukan maka pernyataan itu dihilangkan saja. Gambar pada soal harus jelas dan berfungsi dengan baik. Pada analisis kualitatif terdapat 2 soal yang memiliki gambar yang tidak berfungsi dengan baik.

Hal selanjutnya yang perlu diperhatikan dalam membuat soal adalah menggunakan bahasa yang sesuai dengan kaidah bahasa Indonesia. Seperti penulisan huruf kapital untuk semua kata yang dianggap penting yang tidak tepat. Penulisan kata yang penting dapat dengan memiringkan tulisan atau menebalkan tulisan tanpa membuat tulisan berhuruf kapital seluruhnya. Pada penulisan di awal kalimat harus menggunakan huruf kapital baik pada 
pokok soal maupun pada pilihan jawaban. Jumlah titik-titik (...) pada pokok soal tidak boleh melebihi dari tiga buah titik.

Tabel 4. Hasil Analisis Validitas Butir Soal

\begin{tabular}{ccc}
\hline Sekolah & Jumlah & Persentase \\
\hline $\begin{array}{c}\text { MA Ponpes } \\
\text { Khairul Ummah } \\
\text { Batu Gajah }\end{array}$ & 29 & $72,5 \%$ \\
\hline $\begin{array}{c}\text { MA Nurul Falah } \\
\text { Air Molek }\end{array}$ & 31 & $77,5 \%$ \\
\hline
\end{tabular}

Validitas item pada soal ujian semester ganjil mata pelajaran kimia kelas $\mathrm{X}$ MA Pondok Pesantren Khairul Ummah Batu Gajah dan MA Nurul Falah Air Molek Kabupaten Indragiri Hulu tahun pelajaran 2015/2016 di hitung menggunakan teknik korelasi point biserial $\left(\gamma_{p b i}\right)$. Hasil perhitungan selanjutnya diinterpretasikan dengan membandingkan $\gamma_{p b i}$ yang diperoleh dengan $\mathrm{r}$ tabel pada taraf signifikansi $5 \%$ dan db (derajat kebebasan) $=$ $\mathrm{N}-2$, apabila $\gamma_{\mathrm{pbi}}>\mathrm{r}_{\mathrm{t}}$ maka butir soal tersebut valid.

Teknik korelasi point biserial $\left(\gamma_{p b i}\right)$ di gunakan karena validitas item adalah sebuah item dikatakan valid apabila mempunyai dukungan yang besar terhadap skor total. Skor pada item menyebabkan skor pada total menjadi tinggi atau rendah. Dengan kata lain bahwa sebuah item memiliki validitas yang tinggi jika skor pada item mempunyai kesejajaran dengan skor total. Kesejajaran ini diartikan dengan korelasi.[4]

Soal ujian semester ganjil mata pelajaran kimia kelas X MA Pondok Pesantren Khairul Ummah Batu Gajah tahun pelajaran 2015/2016 berjumlah 40 butir soal dengan testee berjumlah 100 siswa. Derajat kebebasan yang di gunakan adalah 98 (100-2) dengan taraf signifikansi 5\%. Sehingga diperoleh $\mathrm{r}$ tabel sebesar 0,1966. Apabila $\gamma_{p b i} \geq 0,1966$ maka butir soal tersebut dinyatakan valid. Hasil analisis validitas butir soal menunjukkan bahwa terdapat 29 butir soal $(72,5 \%)$ valid dan soal tidak valid berjumlah 11 butir soal $(27,5 \%)$.

Soal ujian semester ganjil mata pelajaran kimia kelas X MA Nurul Falah Air Molek tahun pelajaran 2015/2016 berjumlah 40 butir soal dengan testee berjumlah 71 siswa. Derajat kebebasan yang di gunakan adalah 69 (71-2) dengan taraf signifikansi 5\%. Sehingga diperoleh $\mathrm{r}$ tabel sebesar 0,2335. Apabila $\gamma_{p b i} \geq$ 0,2335 maka butir soal tersebut dinyatakan valid. Hasil analisis validitas butir soal menunjukkan bahwa terdapat 31 butir soal $(77,5 \%)$ valid dan soal tidak valid berjumlah 9 butir soal $(22,5 \%)$.

Soal yang tidak valid tersebut belum mampu mengukur apa yang seharusnya diukur di dalam butir soal tersebut. Sebagaimana validitas item suatu tes adalah ketepatan mengukur yang dimiliki oleh sebutir item dalam mengukur apa yang seharusnya diukur lewat butir item tersebut.[6] Selanjutnya butir soal yang valid di analisis daya pembeda, tingkat kesukaran, dan fungsi distraktornya untuk mengetahui kualitasnya. Sedangkan butir soal yang tidak valid secara empiris ditolak dan tidak digunakan. Namun butir soal yang tidak valid perlu diuji ulang karena terdapat beberapa soal yang tidak valid memiliki masalah secara kualitatif seperti soal yang tidak sesuai dengan indikator soal.

Tabel 5. Hasil Analisis Reliabilitas Tes

\begin{tabular}{cc}
\hline Nama Sekolah & $\begin{array}{c}\text { Koefisien } \\
\text { Reliabilitas Tes }\end{array}$ \\
\hline $\begin{array}{c}\text { MA Ponpes Khairul } \\
\text { Ummah Batu Gajah }\end{array}$ & 0,65 \\
\hline $\begin{array}{c}\text { MA Nurul Falah Air } \\
\text { Molek }\end{array}$ & 0,75 \\
\hline
\end{tabular}

Reliabilitas tes di hitung menggunakan pendekatan single test-single trial dengan menggunakan formula Kuder-Richardson $\left(\mathrm{KR}_{20}\right)$. Hasil perhitungan selanjutnya di interpretasikan dengan nilai 0,70 . Apabila $r_{11} \geq$ 0,70 maka tes hasil belajar memiliki reliabilitas yang tinggi.

Soal ujian semester ganjil mata pelajaran kimia kelas X MA Pondok Pesantren Khairul Ummah Batu Gajah tahun pelajaran 2015/2016 berjumlah 40 butir soal dengan testee berjumlah 100 siswa. Hasil perhitungan diperoleh reliabilitas tes $\left(\mathrm{r}_{11}\right)$ sebesar 0,65 jika dibulatkan menjadi 0,7 dengan nilai $\mathrm{S}^{2}$ sebesar 22,6619 dan $\sum p q$ sebesar 8,409. Hasil perhitungan tersebut menunjukkan bahwa $\mathrm{r}_{11} \geq$ 0,70 . 
Soal ujian ujian semester ganjil mata pelajaran kimia kelas X MA Nurul Falah Air Molek tahun pelajaran 2015/2016 berjumlah 40 butir soal dengan testee berjumlah 71 siswa. Hasil perhitungan diperoleh reliabilitas tes $\left(\mathrm{r}_{11}\right)$ sebesar 0,76 dengan nilai $\mathrm{S}^{2}$ sebesar 32,8967 dan $\sum p q$ sebesar 8,6765. Hasil perhitungan tersebut menunjukkan bahwa $r_{11} \geq 0,70$.

Berdasarkan penjelasan tersebut dapat disimpulkan bahwa pada soal ujian memiliki reliabilitas tinggi. Sehingga soal yang digunakan tersebut dapat dipercaya dan memberikan hasil yang sesuai dengan kenyataan (kemampuan siswa yang sebenarnya).

Realibilitas berhubungan dengan masalah kepercayaan. Suatu tes dapat dikatakan mempunyai taraf kepercayaan yang tinggi jika tes tersebut dapat memberikan hasil yang tetap. Reliabilitas terkait dengan pemotretan berkalikali. Instrumen yang baik adalah instrument yang dapat dengan ajeg memberikan data yang sesuai dengan kenyataan.[4]

Tabel 6. Hasil Analisis Daya Pembeda Butir Soal MA Ponpes Khairul Ummah Batu Gajah

\begin{tabular}{ccc}
\hline Kategori & Jumlah & Persentase \\
\hline Sangat Jelek & 2 & $5 \%$ \\
\hline Jelek & 12 & $30 \%$ \\
\hline Cukup & 13 & $32.5 \%$ \\
\hline Baik & 13 & $32,5 \%$ \\
\hline Sangat Baik & 0 & $0 \%$ \\
\hline Jumlah & 40 & $100 \%$ \\
\hline
\end{tabular}

Tabel 7. Hasil Analisis Daya Pembeda Butir Soal MA Nurul Falah Air Molek

\begin{tabular}{ccc}
\hline Kategori & Jumlah & Persentase \\
\hline Sangat Jelek & 1 & $2,5 \%$ \\
\hline Jelek & 6 & $15 \%$ \\
\hline Cukup & 17 & $42,5 \%$ \\
\hline Baik & 14 & $35 \%$ \\
\hline Sangat Baik & 2 & $5 \%$ \\
\hline Jumlah & 40 & $100 \%$ \\
\hline
\end{tabular}

Daya pembeda pada soal ujian semester ganjil mata pelajaran kimia kelas $\mathrm{X}$ MA
Pondok Pesantren Khairul Ummah Batu Gajah dan MA Nurul Falah Air Molek Kabupaten Indragiri Hulu tahun pelajaran 2015/2016 di hitung menggunakan formula indeks diskriminasi dengan membagi testee kedalam 2 kelompok yaitu $27 \%$ kelompok atas dan $27 \%$ kelompok bawah. Hasil perhitungan selanjutnya di interpretasikan terhadap indeks daya beda dengan patokan sebagai berikut:[4]

1) D : 0,00-0,19: jelek (poor)

2) D : 0,20-0,39: cukup (satisfactory)

3) D : 0,40-0,69: baik (good)

4) $\mathrm{D}: 0,70-1,00:$ baik sekali (excellent)

5) D : negatif, sangat jelek, semuanya tidak baik, jadi semua butir soal yang mempunyai nilai D negatif sebaiknya dibuang saja.

Hasil analisis daya beda pada soal ujian semester ganjil mata pelajaran kimia kelas $\mathrm{X}$ MA Pondok Pesantren Khairul Ummah Batu Gajah tahun pelajaran 2015/2016 diperoleh sebanyak 2 butir soal (5\%) dengan kategori sangat jelek, 12 butir soal (30\%) dengan kategori jelek, 13 butir soal $(32,5 \%)$ dengan kategori cukup, 13 butir soal $(32,5 \%)$ dengan kategori baik, dan 0 butir soal $(0 \%)$ dengan kategori sangat baik. Selanjutnya hasil analisis tingkat kesukaran MA Nurul Falah Air Molek tahun pelajaran 2015/2016 diperoleh sebanyak 1 butir soal $(2,5 \%)$ dengan kategori sangat jelek, 6 butir soal (15\%) dengan kategori jelek, 17 butir soal $(42,5 \%)$ dengan kategori cukup, 14 butir soal (35\%) dengan kategori baik, dan 2 butir soal (5\%) dengan kategori sangat baik.

Daya pembeda item adalah kemampuan suatu butir soal untuk membedakan (mendiskriminasi) antara testee yang berkemampuan tinggi dengan testee yang berkemampuan rendah.[4] Sehingga butir soal yang memiliki kategori jelek dan jelek sekali tidak dapat membedakan antara siswa kelompok atas dan kelompok bawah.

Soal yang memiliki daya beda jelek sekali pada MA Pondok Pesantren Khairul Ummah Batu Gajah adalah butir soal nomor 3 dan 38. Butir soal nomor 3 dipilih oleh 19 kelompok atas dan 20 kelomok bawah. Butir soal nomor 38 dipilih oleh 12 kelompok bawah 12 kelompok atas. Sedangkan soal yang memiliki daya beda jelek sekali pada MA Nurul Falah 
Air Molek adalah butir soal nomor 15. Butir soal nomor 15 dipilih oleh 12 kelompok atas dan 13 kelomok bawah.

Soal yang memiliki daya beda jelek sekali pada kedua sekolah ternyata juga merupakan soal yang tidak valid. Sehingga butir soal nomor 3 dan 38 pada MA Pondok Pesantren Khairul Ummah Batu Gajah dan butir soal nomor 15 pada MA Nurul Falah Air Molek ditolak.

Soal yang memiliki daya beda jelek pada MA Pondok Pesantren Khairul Ummah Batu Gajah adalah butir soal nomor 1, 4, 5, 7, 9, 30, $31,32,35,36,37$, dan 40. Butir soal nomor 4, $7,9,30,31,32,35,36$, dan 37 ternyata juga merupakan soal yang tidak valid sehingga ditolak. Sedangkan butir soal nomor 1, 5, dan 40 merupakan butir soal yang valid sehingga dapat direvisi.

Soal yang memiliki daya beda jelek sekali pada MA Nurul Falah Air Molek adalah butir soal nomor $6,7,8,11,14$, dan 20 . Butir soal nomor $6,7,11,14$, dan 20 ternyata juga merupakan soal yang tidak valid sehingga ditolak. Sedangkan butir soal nomor 8 merupakan butir soal yang valid sehingga dapat direvisi.

Namun dalam merevisi soal yang memiliki daya beda jelek, perlu diperhatikan penyebabnya. soal yang memiliki daya beda jelek dapat terjadi karena butir soal berkategori mudah atau terlalu sukar. Apabila butir soal berkategori mudah, siswa berkemampuan tinggi dan rendah dapat menjawab dengan benar soal tersebut. Apabila butir soal berkategori sangat sukar siswa berkemampuan tinggi akan sulit menjawabnya begitupula dengan siswa berkemampuan rendah. Pada soal ujian disekolah soal berkategori mudah dan sukar diperlukan. Sehingga butir soal seperti ini tidak dapat direvisi.

Tabel 8. Hasil Analisis Tingkat Kesukaran Butir Soal MA Ponpes Khairul Ummah Batu Gajah

\begin{tabular}{ccc}
\hline Kategori & Jumlah & Persentase \\
\hline Sukar & 7 & $17,5 \%$ \\
\hline Sedang & 26 & $65 \%$ \\
\hline Mudah & 7 & $17,5 \%$ \\
\hline
\end{tabular}

\begin{tabular}{ccc}
\hline Jumlah & 40 & $100 \%$ \\
\hline $\begin{array}{c}\text { Tabel 9. Hasil Analisis Tingkat Kesukaran } \\
\text { Butir Soal MA Nurul Falah Air Molek }\end{array}$ \\
\hline Kategori & Jumlah & Persentase \\
\hline Sukar & 6 & $15 \%$ \\
\hline Sedang & 25 & $62,5 \%$ \\
\hline Mudah & 9 & $22,5 \%$ \\
\hline Jumlah & 40 & $100 \%$ \\
\hline
\end{tabular}

Tingkat kesukaran di hitung menggunakan formula yang dikemukakan oleh Du Bois. Hasil perhitungan selanjutnya di interpretasikan terhadap indeks kesukaran soal dengan patokan sebagai berikut:[4]

1) Soal dengan $P 0,00$ sampai 0,30 adalah soal sukar.

2) Soal dengan $P$ 0,31 sampai 0,70 adalah soal sedang.

3) Soal dengan $P$ 0,71 sampai 1,00 adalah soal mudah.

Hasil analisis tingkat kesukaran pada soal ujian semester ganjil mata pelajaran kimia kelas X MA Pondok Pesantren Khairul Ummah Batu Gajah tahun pelajaran 2015/2016 diperoleh sebanyak 7 butir soal (17,5\%) dengan ketegori sukar, 26 butir soal (65\%) dengan kategori sedang, dan 7 butir soal (17,5\%) dengan kategori mudah. Selanjutnya hasil analisis tingkat kesukaran MA Nurul Falah Air Molek tahun pelajaran 2015/2016 diperoleh sebanyak 6 butir soal (15\%) dengan ketegori sukar, 25 butir soal $(62,5 \%)$ dengan kategori sedang, dan 9 butir soal $(22,5 \%)$ dengan kategori mudah.

Suatu tes hasil belajar yang diberikan kepada siswa dikatakan memiliki keseimbangan apabila proposi soal antara sukar:sedang:mudah dengan perbandingan 3:4:3 atau 2:5:3.[7] Setelah di lakukan analilis terhadap validitas dan daya pembeda pada soal ujian semester ganjil mata pelajaran kimia kelas X MA Pondok Pesantren Khairul Ummah Batu Gajah tahun pelajaran 2015/2016, diperoleh proposi soal antara sukar:sedang:mudah dengan perbandingan 5:19:5. Sehingga tes hasil belajar belum memiliki proporsi soal yang seimbang. Rekomendasi proporsi soal antara sukar:sedang:mudah yang seimbang untuk tes 
hasil belajar ini adalah 8:13:8 dengan rasio perbandingan $3: 4: 3$. Sehingga soal dengan kategori sukar ditambahkan 3 butir soal, soal dengan kategori sedang dikurangkan 6 butir soal, dan soal dengan kategori mudah ditambahkan 3 butir soal.

Pada soal ujian semester ganjil mata pelajaran kimia kelas X MA Nurul Falah Air Molek tahun pelajaran 2015/2016 diperoleh proposi soal antara sukar:sedang:mudah dengan perbandingan 7:19:5. Sehingga tes hasil belajar belum memiliki proporsi soal yang seimbang. Rekomendasi proporsi soal antara sukar:sedang:mudah yang seimbang untuk tes hasil belajar ini adalah 9:13:9 dengan rasio perbandingan $3: 4: 3$. Sehingga soal dengan kategori sukar ditambahkan 2 butir soal, soal dengan kategori sedang dikurangkan 6 butir soal, dan soal dengan kategori mudah ditambahkan 4 butir soal.

Tabel 10. Persentase Kategori Fungsi Distraktor (Pengecoh) Butir Soal MA Ponpes Khairul Ummah Batu Gajah

\begin{tabular}{ccc}
\hline Kategori & Jumlah & Persentase \\
\hline Sangat Baik & 45 & $28,125 \%$ \\
\hline Baik & 45 & $28,125 \%$ \\
\hline Kurang Baik & 30 & $18,75 \%$ \\
\hline Jelek & 26 & $16,25 \%$ \\
\hline Sangat Jelek & 14 & $8,75 \%$ \\
\hline Jumlah & 160 & $100 \%$ \\
\hline
\end{tabular}

Tabel 11. Persentase Kategori Fungsi Distraktor (Pengecoh) Butir Soal MA Nurul Falah Air Molek

\begin{tabular}{ccc}
\hline Kategori & Jumlah & Persentase \\
\hline Sangat Baik & 60 & $37,5 \%$ \\
\hline Baik & 30 & $18,75 \%$ \\
\hline Kurang Baik & 45 & $28,125 \%$ \\
\hline Jelek & 20 & $12,5 \%$ \\
\hline Sangat Jelek & 5 & $3,125 \%$ \\
\hline Jumlah & 160 & $100 \%$ \\
\hline
\end{tabular}

Kategori distraktor yang ditolak adalah kategori jelek dan sangat jelek.[8] Butir soal yang baik adalah butir soal yang distraktornya dipilih secara merata oleh testee. Artinya distraktor yang baik bukan distraktor yang paling banyak dipilih oleh testee. Butir soal yang jelek bisa saja adalah distraktor yang dipilih paling banyak oleh testee namun distraktor yang lain dipilih sangat sedikit oleh testee atau sebaliknya. Sehingga pada MA Pondok Pesantren Khairul Ummah Batu Gajah terdapat $40(25 \%)$ distraktor yang ditolak yaitu 26 distraktor (16,25\%) dengan kategori jelek, dan 14 distraktor $(8,75 \%)$ dengan kategori sangat jelek. Pada MA Nurul Falah Air Molek terdapat $25(15,625)$ distraktor yang ditolak yaitu 20 distraktor (12,5\%) dengan kategori jelek, dan 5 distraktor $(3,125 \%)$ dengan kategori sangat jelek.

\section{SIMPULAN}

Kualitas butir soal ujian semester ganjil mata pelajaran kimia kelas $\mathrm{X}$ MA Ponpes Khairul Ummah Batu Gajah tahun pelajaran 2015/2016 secara kualitatif terdapat 20 butir soal $(50 \%)$ yang sesuai dengan semua aspek materi, konstruksi, dan bahasa yang ditelaah; dan 20 butir soal $(50 \%)$ tidak sesuai dengan aspek yang ditelaah dan diperbaiki. Pada MA Nurul Falah Air Molek terdapat 19 butir soal (47,5\%) yang sesuai dengan semua aspek materi, konstruksi, dan bahasa yang ditelaah; dan 21 butir soal $(52,5 \%)$ tidak sesuai dengan aspek yang ditelaah dan diperbaiki.

Kualitas butir soal ujian secara kuantitatif, pada MA Ponpes Khairul Ummah terdapat 29 soal valid; memiliki daya pembeda sangat jelek, jelek, cukup, dan baik berturut-turut sebanyak 2, 12, 13, dan 13 soal; belum memiliki keseimbangan pada tingkat kesukaran; dengan distraktor sangat baik, baik, kurang baik, jelek, dan sangat jelek berturut-turut sebanyak 45,45 , 30, 26, dan 14; memiliki reliabilitas tes sebesar 0,65. Pada MA Nurul Falah terdapat 31 soal valid; memiliki daya pembeda sangat jelek, jelek, cukup, baik, dan sangat baik berturutturut sebanyak 1, 6, 17, 14, dan 2 soal; belum memiliki keseimbangan pada tingkat kesukaran; dengan distraktor sangat baik, baik, kurang baik, jelek, dan sangat jelek berturutturut sebanyak $60,30,45,20$, dan 5 ; memiliki reliabilitas tes sebesar 0,76 .

\section{REFERENSI}


[1] H. A. Tri Handani, "Validitas dan Reliabilitas Soal Tengah Semester Genap Kaitannya dengan Ketercapaian Tujuan Pembelajaran Bahasa Indonesia Kelas VIIIA SMP Negeri 2 Banyudono Tahun Pelajaran 2013/1014," Univ. Res. Colloq. 2015 ISSN 2407-9189, pp. 193 206, 2015.

[2] E. Djanuarsih, "Validitas dan Reliabilitas Butir Soal," E-Jurnal Dinas Pendidik. Kota Surabaya, vol. 3, pp. 113.

[3] I. Basuki dan Hariyanto, Asesmen Pembelajaran. Bandung: PT. Remaja Rosdakarya, 2015.

[4] S. Arikunto, Dasar-Dasar Evaluasi Pendidikan. Jakarta: Bumi Akasara,
2013.

[5] F. D. Susanti, Evaluasi Pembelajran Bahasa Arab. Pekanbaru: Educationmattersmost Publishing, 2012.

[6] A. Sudijono, Pengantar Evaluasi Pendidikan. Jakarta: Rajawali Pers, 2013.

[7] M. Nuswowati, A. Binadja, K. Efti, and N. Ifada, "Pengaruh Validitas Dan Reliabilitas Butir Soal Ulangan Akhir Semester Bidang Studi Kimia Terhadap Pencapaian Kompetensi," J. Inov. Pendidik. Kim., vol. 4, no. 1, pp. 566573, 2010.

[8] Z. Arifin, Evaluasi Pembelajaran Prinsip Teknik Prosedur. Bandung: PT. Remaja Rosdakarya, 2011. 